\title{
IMAGING FEATURES AND TREATMENT OF AN INTRADURAL LUMBAR CYSTIC SCHWANNOMA
}

\author{
Guilherme Borges ${ }^{1}$, Leonardo Bonilha1, Marcílio Proa Jr. ${ }^{1}$, Yvens Barbosa Fernandes ${ }^{1}$ \\ Ricardo Ramina1, Veronica Zanardi², Jose Ribeiro Menezes²
}

\begin{abstract}
Spinal schwannomas are frequently observed among patients treated in a reference neurosurgery center. Cystic spinal schwannomas, however, are very scantly found. Due to its indolent behavior and benign course, the diagnosis of schwannomas may pose a challenge to the care giver, and the imaging findings can be misleading. In this article, we illustrate an example of a pauci-symptomatic 55 year-old male patient whose complaint was solely a non specific lumbar pain. Investigation revealed a large cystic lesion comprising the lower lumbar intradural space. He was then treated with microneurosurgical technique involving complete removal of the tumor and reconstruction of the duramater. Histological and immunohystochemical diagnosis were consistent with cystic schwannoma. The patient presented with complete recovery of his symptom. In this article we aim to emphasize the clinical presentation and treatment of lumbar spine schwannomas, and to illustrate the imaging findings within this uncommon case.
\end{abstract}

KEY WORDS: schwannoma, cystic tumor, nerve sheath tumor, neurinoma.

\begin{abstract}
Achados imagenológicos e tratamento de um schwannoma cístico intradural lombar
RESUMO - O schwannoma cístico intra-espinal é tumor muito raro e poucos casos estão descritos na literatura: são usualmente assintomáticos e somente diagnosticados quando atingem grande tamanho causando compressão radicular. Com o intuito de ilustrar as armadilhas existentes re fe rentes ao diagnóstico e tratamento desse tipo de tumor, nós relatamos um caso raro, focando nos passos da investigação e terapêutica. É descrito o caso de um paciente de 55 anos que apresentava apenas queixas de dor lombar. A investigação revelou uma lesão cística extensa na região intradural lombar inferior. O tumor foi totalmente ressecado por técnica micro neurocirúrgica, sendo a dura-máter reconstruída. O diagnóstico patológico e imuno-histoquímico evidenciou tratar-se de um schwannoma cístico. Neste artigo, nós procuramos enfatizar as características clínicas e tratamento de schwannomas lombares, ilustrando os achados imagenológicos desse caso incomum.
\end{abstract}

PALAVRAS-CHAVE: schwannoma, tumor cístico, tumor de bainha nervosa, neurinoma.

Schwannomas are benign tumors of the peripheral nervous system, arising from Schwann cells'. Schwannomas can occur virtually in any body location where peripheral or cranial nerves are present $^{2}$, and they correspond to $8 \%$ of primary intracranial and $29 \%$ of primary spinal tumors ${ }^{1}$. Within the spinal region, Prevedello et al. have investigated the prevalence of diffe rent extramedullary intradural spinal tumors and observed that schwannomas comprised $66 \%$ of all cases ${ }^{3}$. The lumbar region is one of the most common sites for occurrence of spinal schwannomas, as demonstrated by Conti et al., who studied the distribution of spinal schwannomas and reported that $48 \%$ lie within the lumbar spine ${ }^{4}$. While schwannomas occurring within the lumbar spine are not rare, large and predominantly cystic schwannomas occurring in the lumbar spine have scantly been demonstrated, even though it is well defined that benign schwannomas can eventually display degenerative changes defined by cyst formation, calcification, hemorrhage and hyalinization ${ }^{1}$. Interestingly, large schwannomas within the lumbar spine may go unnoticed for a large time span mainly due to the indolent growth of the tumor and the paucity of symptoms generated. With a more malleable structure, a cystic schwannoma may pose a challenge to the diagnosis.

We present a rare case of a patient with a large cystic schwannoma in the lumbar region. We aim to emphasize the diffe rential diagnosis of cystic masses of the intraspinal region by illustrating the

State University of Campinas (UNICAMP) Campinas SP, Brasil: ${ }^{1}$ Neurology and Neurosurgery Department; ${ }^{2}$ Radiology Department. Received 15 October 2004, received in final form 27 December 2005. Accepted 14 March 2005. 
clinical picture, imaging findings and treatment of this unique case. This report was approved by the Committee of Ethics and Research of our Institution (UNICAMP).

\section{CASE}

A 55-year-old man without remarkable previous medical history was admitted in our Hospital due to a 12-month history of lumbar pain with a poorly defined i rradiation to both lower limbs. His general physical examination was normal and did not exhibit signs compatible with neuro fibromatosis. His neurological physical examination failed to disclose signs of radicular irritation, motor or sensory deficits. Magnetic resonance imaging (MRI) (Fig 1) depicted an extensive lesion (6.0x1.8x $1.8 \mathrm{~cm}$ ) extending from the $4^{\text {th }}$ to $5^{\text {th }}$ lumbar vertebrae almost completely constituted by a large cyst. Gadolinium contrasted MRI depicted a ring-like enhancement of the cyst. Tumor was totally removed by microneurosurgical technique (Fig 2). The remaining thin duramater was not large enough for primary repair, and an artificial graft (DuraGen ${ }^{\mathrm{TM}}$ ) was successfully used to accomplish a water tight seal dura-mater closure. Histological examination of the excised specimen revealed typical schwannoma cell nuclei (Fig 3A). Immunohystochemical study included staining for S-100 protein and NGFR (nerve growth factor receptor), which were both positive diffusely across the tumor cells (Fig $3 B$ and 3 C). The immunohystochemical analysis alongside with the histological observations confirmed the diagnosis of a cystic schwannoma. After an unremarkable postoperative period, the patient experienced a complete remission of preoperative symptoms. At a follow-up visit performed 12 months after surgery, the patient was asymptomatic.

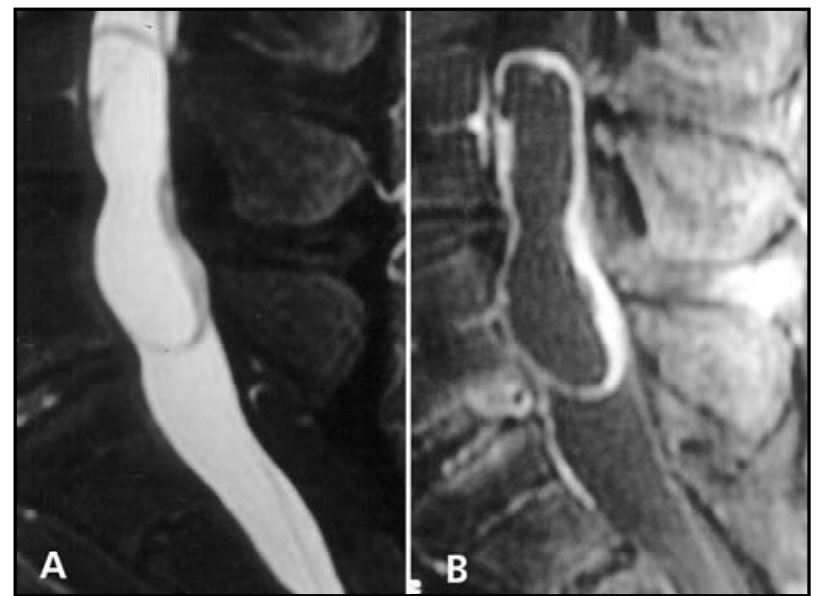

Fig 1. Pre-operative sagittal MRI scan of the lumbar spine: In A) T2-weighted image showing an intradural cystic lesion; In B) T1-weighted image (gadolinium injection) showing the enhanced thin ring-like cystic tumor capsule.

\section{DISCUSSION}

Schwannomas are slow growing benign tumors. They are usually encapsulated, and rarely undergo malignant transformation ${ }^{1}$. Schwannomas arise from the Schwann cells of the nerve sheath, and they comprise the most common tumor type affecting the peripheral nerve $\mathrm{s}^{1}$. The most common location of schwannomas are around peripheral nerves in the extradural space. Intracranial schwannomas have also been observed, and they usually arise from the facial, trigeminal, or vestibular nerves $^{5,6}$. Conspicuously, schwannomas are more frequently observed in patients with neurofibromatosis type $2^{1}$, schwannomas can be observed in rather

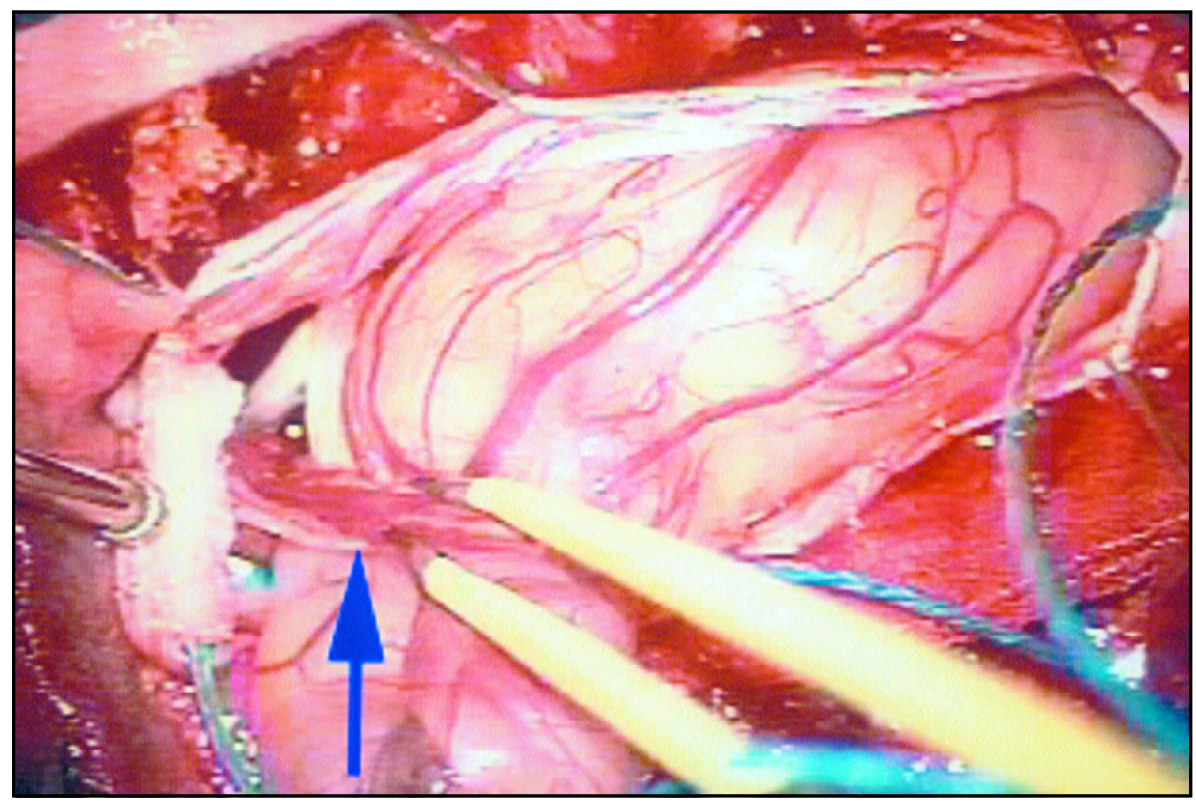

Fig 2. Intra-operative image show ing the cystic lesion after separa tion from the roots by blunt micro dissection. A rootlet remains adher ent to the tumor disappearing inside its capsule (arrow). 


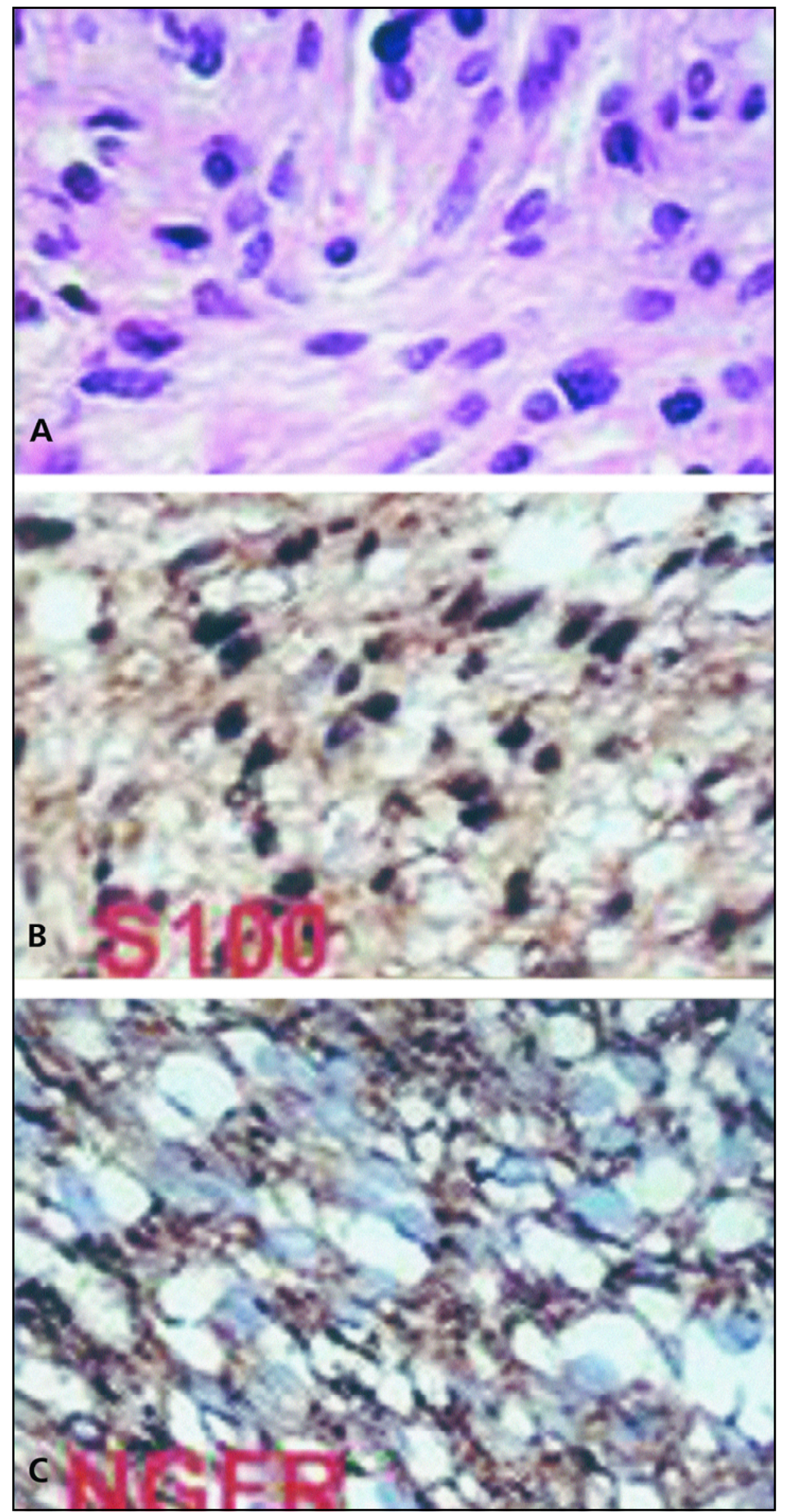

Fig 3. A) Hematoxylin-eosin study of the histological section of the excised tumor reveals typical schwannoma cell nuclei. B) S-100 p rotein preparation of the histo logical section reveals intense staining. C) Histological prepara tion for investigation of NGFR (nerve growth factor receptor) antigen shows intense positive reaction. 
rare locations ${ }^{7}$. Women and men are equally affected by schwannomas ${ }^{1}$, and the literature is prolific in showing cases of schwannomas affecting a large age range ${ }^{2}$, albeit there is a predefined predilection for occurrence in between the fourth to sixth decades of life'.

Benign schwannomas can occasionally display degenerative changes that are encompassed by cyst formation, calcifications, hemorrhage and hyalinization. When multiple degenerative changes are encountered, schwannomas fit into the category of "ancient schwannomas", which are extremely benign in course, rarely demanding any form of treatment ${ }^{8}$. Specifically, the cystic degeneration of schwannomas occurring in isolation, i.e., without additional features of ancient schwannomas, is scantly encountered. Cystic degenerations have been observed in the orbital region ${ }^{9}$, in the olfactory groove ${ }^{10}$, in the tentorial hiatus and posterior cavernous sinus ${ }^{11}$, in the presacral region ${ }^{12,13}$, within the pancreas ${ }^{14}$, in the maxillary sinus ${ }^{15}$, within the spinal cord ${ }^{16-18}$, and intraventricular ${ }^{19}$. Cystic schwannomas have also been observed surro unding cranial nerves such as the vestibular nerve ${ }^{20}$, the vagus nerve ${ }^{8}$ and within the jugular foramen ${ }^{21}$. Only seven cases of cystic lumbar nerve sheath tumors have been described in the literature pointing out its resonance magnetic imaging presentation $^{22,23}$.

As schwannomas are benign tumors with a slow $g$ rowth rate, the diagnosis of extracranial schwannomas my pose a challenge to the care giver when few symptoms are observed. In the case we report, there is a striking contrast with the paucity of symptoms and the size of the tumor. This highlights the importance of suspecting of a cystic lumbar nerve sheath tumor when symptoms associated to lumbar spinal cord, or nerve roots compression are encountered. Moreover, schwannomas should be included in the differential diagnosis of a cystic mass in the spinal region.

Diffe rently from cystic calcified schwannomas, i.e., "ancient schwannomas", cystic schwannomas possibly behave in a similar fashion to solid schwannomas. Therefore the treatment of a cystic schwannoma in that setting should involve radical surgical excision of the tumor, which, as demonstrated in this case report, can be performed without inflicting any harm to the patient.

In conclusion, cystic schwannomas are rare benign tumors of the lumbar region. Clinical symp- toms are usually due to the compression of lumbar spine or nerve roots structures, but given the slow growth of the tumor, few symptoms can be observed up until the tumor has reached a large mass. The treatment of cystic and non-calcified schwannomas involves safe radical excision of the lesion.

\section{REFERENCES}

1. Kleihues P, Cavenee WK. Pathology and genetics of tumours of the nervous system. Lyon: World Health Organization, 1997.

2. Borges G, Guerreiro MM, Piovesana AM. Infratentorial malignant neurinoma: report of a case. Arq Neuropsiquiatr 1986;44:206-209.

3. Prevedello DM, Koerbel A, Tatsui CE, et al. Prognostic factors in the treatment of the intradural extramedullary tumors: a study of 44 cases. Arq Neuropsiquiatr 2003;61:241-247.

4. Conti P, Pansini G, Mouchaty H, Capuano C, Conti R. Spinal neurinomas: retrospective analysis and long-term outcome of 179 consecutively operated cases and review of the literature. Surg Neurol 2004;61: 34-43.

5. Ramina R, Maniglia JJ, Meneses MS, et al. Acoustic neurinomas: diagnosis and treatment. Arq Neuropsiquiatr 1997;55:393-402.

6. Ford LC, Cruz RM, Rumore GJ, Klein J. Cervical cystic schwannoma of the vagus nerve: diagnostic and surgical challenge. J Otolaryngol 2003;32:61-63.

7. Ramina R, Maniglia JJ, Fernandes YB, et al. Jugular forâmen tumors: diagnosis and treatment. Neurosurg Focus, 2004:17:E5.

8. Hide IG, Baudouin CJ, Murray SA, Malcolm AJ. Giant ancient schwannoma of the pelvis. Skeletal Radiol 2000;29:538-542.

9. Tokugawa J, Nakao Y, Mori K, Maeda M. Orbital cystic neurinoma. Acta Neurochir (Wien ) 2003;145:605-606.

10. Shenoy SN, Raja A. Cystic olfactory groove schwannoma. Neurol India 2004;52:261-262.

11. Du R, Dhoot J, McDermott MW, Gupta N. Cystic schwannoma of the anterior tentorial hiatus: case report and review of the literature. Pediatr Neurosurg 2003;38:167-173.

12. Andonian S, Karakiewicz PI, Herr HW. Presacral cystic schwannoma in a man. Urology 2003;62:551.

13. Ogose A, Hotta T, Sato S, Takano R, Higuchi T. Presacral schwannoma with purely cystic form. Spine 2001;26:1817-1819.

14. Tan G, Vitellas K, Morrison C, Frankel WL. Cystic schwannoma of the pancreas. Ann Diagn Pathol 2003;7:285-291.

15. Sarioglu S, Ozkal S, Guneri A, et al. Cystic schwannoma of the maxillary sinus. Auris Nasus Larynx 2002;29:297-300.

16. Palma L, Mariottini A. Cystic ectopic schwannoma extending anteriorly from the pontomedullary cistern to the thoracic spinal cord: case illustration. J Neurosurg Spine 2003;98:113.

17. Bauer M, Brock M, Cervos-Navarro J, Prosenc N, Marx P. [Intraspinal neurinoma in the thoracolumbar junction presenting unusual symptoms: the diff e rential diagnosis of lumbago]. Dtsch Med Wochenschr 1994;119:628-630.

18. Shen WC, Lee SK, Chang CY, Ho WL. Cystic spinal neurilemmoma on magnetic resonance imaging. Neuroradiology 1992;34:447-448.

19. Barbosa MD, Rebelo O, Barbosa P, Goncalves J, Fernandes R. Cystic intraventricular schwannoma: case report and review of the literature. Neurocirugia (Astur) 2001;12:56-60.

20. Muzumdar DP, Goel A, Pakhmode CK. Multicystic acoustic neurinoma: report of two cases. J Clin Neurosci 2002;9:453-455.

21. Carvalho GA, Tatagiba M, Samii M. Cystic schwannomas of the jugular foramen: clinical and surgical remarks. Neurosurgery $2000 ; 46$ : 560-566.

22. Parmar H, Patkar D, Gadani S, Shah J. Cystic lumbar nerve sheath tumours: MRI features in five patients. Australas Radiol 2002;45: 123-127.

23. Shiono T, Yoshikawa K, Iwasaki N. Huge Lumbar spinal cystic neurinomas with unusual MR findings. AJNR 1995(Suppl)16:S881-S882. 